\title{
PASSIONARY AS A POTENTIAL OF INTERNAL MOTIVATION OF THE SERVICE COMPANY \\ Borodai V.A. ${ }^{1}$, Dudkina O.V. ${ }^{2}$ (Russian Federation) \\ Email: Borodai327@scientifictext.ru
}

\author{
${ }^{1}$ Borodai Vladimir Aleksandrovich - Doctor of Social Sciences (DSSc), Professor; \\ ${ }^{2}$ Dudkina Ol'ga Vladimirovna - PhD in Social Sciences, Associate Professor, \\ DEPARTMENT OF SERVICE, TOURISM AND HOSPITALITY INDUSTRY, \\ DON STATE TECHNICAL UNIVERSITY, ROSTOV-ON-DON
}

\begin{abstract}
: the article shows that traditional methods of doing business and motivating staff do not guarantee success. The actualization of new ways to increase the efficiency of employees' activity is considered. They are based on the involvement of staff, creativity, creativity and innovation potential. The ability of a leader to focus his subordinates on finding opportunities during a period of turbulent changes becomes the key to the organization's success. It is necessary to change the paradigms of thinking of employees, to transform the settings that are kept within the usual boundaries, to develop pro-activity and to enhance creativity. Passionarity becomes the driving force in achieving the goals of the organization, a positive change in the aggregate state of the internal environment of the service company.
\end{abstract}

Keywords: management methods, passionarity, innovation, creativity, motivation, efficiency.

\section{ПАССИОНАРНОСТЬ КАК ПОТЕНЦИАЛ ВНУТРЕННЕЙ МОТИВАЦИИ СЕРВИСНОЙ КОМПАНИИ} Бородай В.А. ${ }^{1}$ Дудкина О.В.․ำ (Российская Федерация)

\author{
${ }^{1}$ Бородай Владимир Александрович - доктор соичологических наук, профессор; \\ ${ }^{2}$ Дудкина Ольга Владимировна - кандидат сочиологических наук, доцент, \\ кафедра сервиса, туризма и индустрии гостеприимства, \\ Донской государственный технический университет, г. Ростов-на-Дону
}

\begin{abstract}
Аннотация: в статье показано, что традиционные методы ведения бизнеса и мотивации персонала не гарантируют успеха. Рассматриваются актуализационные способы повышения эффективности деятельности сотрудников. Они основаны на вовлеченности персонала, творчестве, креативности и инновационном потенциале. Умение руководителя фокусировать подчиненных на поиске возможностей в период бурных изменений становится залогом успеха организации. Необходимо менять парадигмы мылиления сотрудников, трансформировать установки, которые держат в привычных границах, развивать проактивность и усиливать креативность. Пассионарность становится движущей силой в достижении целей организации, позитивном изменении агрегатного состояния внутренней среды сервисной компании.
\end{abstract}

Ключевые слова: методы управления, пассионарность, инновации, творчество, мотивация, эффективность.

In the market system of coordinates, a serious place is occupied by socio-psychological methods of personnel management. Tonus management today comes to the forefront among other functions of a modern leader. Everything has changed and will never return. In a market economy, the period of uncertainty, crises, storms and storms continues to increase. In terms of the synergetic theory, we can say that the social system is in constant change, random changes in institutional forms (fluctuations) are an indicator of chaos at the micro level of the system and the possibility of its development. Some fluctuations are so strong that they cause a qualitative change, setting the trajectory of future development [1]. This time for business, on the one hand, is complicated, but on the other hand, an incredible number of opportunities are opened, which one could not have noticed before. And the classical approaches to management are replaced by principles and involvement instead of "carrot and stick", orders, "participation instead of submission." After all, the fate of the company is in the hands of its employees.

People are looking for themselves, they want to do what they are interested in, rather than a monotonous routine that requires constant monitoring [2]. The Internet is full of information about the need for right brain activity, creative creativity and focus on opportunities.

The harm of the obsolete system of "stick and carrot". Using the hidden potential of each employee, the organization increases its profitability times. Today people are interested in meanings. An employee wants to do more than just work, but to contribute to something bigger, to serve something. The leaders of many service organizations, realizing this, began to look for ways to develop employees and provide them with greater independence. But the training system does not change the essence of the system "carrot and stick", but more 
serves as "patching holes". This approach does not arouse interest and creative thinking, but strangles it. The employee does not do more than is required to receive the reward. Loyalty of the personnel falls, and business needs means of competent management of people, including, correct, valid estimation and planning of training and development of employees by results of an estimation [3].

All of the above literally requires a modern service organization to create an environment in which people can work with full efficiency at the peak of efficiency. Again we see that we are talking about special conditions in the organization when a person is involved in interesting projects for him when he reveals his potential when his spontaneous impulse to action for the benefit of the service company wakes up. Thus, the vector of formation of the image component of the service company is set, which can not but strengthen the competitive positions in the market, it allows ensuring customer loyalty [4]. This is possible only when the employee is in his place, he knows what contributes to the overall result of the organization. It turns out most important to act in two ways to improve the productivity of the business. One is to use new approaches in training and development, the other is to systematically introduce organizational changes to include internal motivation. It is important for the leader to understand that he will have two innovative processes in parallel - the leader and his associates will learn to apply new methods, and the project team members will learn to interact in a new way [5].

New time requires new approaches. The main challenge for leaders of the 21 st century is to free up the intellectual potential of service organizations. So it's just necessary to change the thinking paradigms of employees, to transform the settings that are kept within the usual boundaries, to develop pro-activity and to enhance creativity. Passionarity becomes the driving force in achieving the organization's goals, a positive change in the aggregate state of the internal environment of the service company. This becomes the key to success. The most pressing issues for business today are creativity, team coaching, facilitation and moderation, employee development, transformation of beliefs, emotional competence, leadership, change management, etc.

I would like to highlight coaching as an innovative technology for business management. This technology literally turns complexity into opportunities. The leader instead of instructions asks questions, helps the subordinate to find the best solution. After all, embody something for him. The subordinate, having independently developed a plan for moving towards the goal, refers to him as to his own. That's why he automatically includes responsibility, increases motivation, there is a sense, self-esteem rises. The favorite saying "solve problems as they come", on the one hand, psychologically alleviates the burden that we freely or unwillingly imposed on ourselves, but, on the other hand, formats our thinking: otherwise, in terms of problems, whether large, small. We do not learn to think [6].

In the age of global change, it is up to the head of the staff to decide whether they can lead the change management process or whether the changes will manage them. In modern conditions, it is necessary to strengthen the spirit of employees through corporate culture: mission, strategy, values. Gradual strengthening of the elements of corporate culture forms the basis for the company's future brand. The employer brand must clearly reflect the cultural facts of the individual service organization. Solid, "right" companies have the courage not to homogenize their culture [7].

When employees know the direction of the company, they have more clarity and awareness, which means less uncertainty and resistance. The vision directs our values into the working environment. A vision is an expression of optimism and hope.

A bright and attractive picture of the Future ignites the eyes and hearts of people. When you "build a Temple, not a building," inner motivation and inspiration are awakening to change the world for the better, which means that there are colossal resources of creative energy. It is difficult to exaggerate the benefits of values shared by employees. They are the foundation of the corporate culture of the company. Corporate culture in the organization specifically implements the integrative function, provides the team with an equilibrium by maintaining the sample and incorporating the person into the existing sociocultural systems, i.e. Acts as a socializing mechanism [8]. Values of the service company are set by the values of the first persons. It is important to formulate them in order to use the power of values for the life of the service company. These are deep internal "motivators" of employees, clients. Today, the mission or mission of a service company is not just slogans, but the meanings for its employees. It is especially important that the wording of the mission does not "fall" in the table, but works, uniting around itself, giving meaning and inspiring employees for everyday "feats." And if it was formulated at one time or "lowered from above," it is simply necessary to work on "introducing" it into the collective.

Time trends guide managers to such mottoes as - reward justice, but get rid of "pests". It is necessary to create a transparent, non-abusive reward system. We must get away from the expected reward "if something", in the unexpected "now, when." It is necessary to carry out analysis and have several options for calculations. Alternative calculations provide the choice of the best option for making a decision, which at the next stage is embodied in the plans [9]. Employees should be paid at least as much as their colleagues in similar organizations that perform a similar job. This will guarantee the prevention of remuneration in a demotivating factor. And if they receive a little more average than the market, the leader will be able to gather the best specialists in the 
industry, reduce turnover and improve the atmosphere in the team. Higher salaries in the long term reduce the costs of the service company.

It is necessary to get rid of "pests" mercilessly. There is such a definition - "let go". Those who have not accepted the new rules for managing the company will leave themselves because of the absolute discomfort of the corporate environment, which will be absolutely alien to them [10]. Yes, it is not easy to dismiss a person. Pity and desire to save and be good are included, but ... a person may simply not be at his place. And if the manager sees that the employee's behavior is contrary to the values and culture of the service company, then it is necessary to get rid of such people immediately. They, like viruses, harm the company, gradually "infecting" the entire body. It is advisable to form "involvement" instead of "obedience." To involve the personnel in solving business problems of the company it is desirable:

First, create an atmosphere in which the balance of "mind and heart" is observed. Companies with a balance of logic, facts and analysis with emotions, energy and enthusiasm are very effective.

Secondly, it is necessary to stimulate the independence of subordinates. Another important factor is the selection of flexible interactive staff [11]. Almost every day you can hear from the leaders of their groans that they want more independence of their subordinates. And this is understandable, then the head has more time for strategy and development of the company. What to do? On the one hand, it is important to enable subordinates to think through ways of achieving their goals and plan their activities. On the other hand, it is necessary to weaken the iron grip of total control. Then there is initiative and creativity and the person readily takes responsibility. Such a policy will allow ... to create an image of the company as a place where everyone would like to work [12]. Today it is necessary to involve employees in setting goals. Why sometimes leaders believe that this is not effective. In addition, after a while, the chief with surprise may find that people have higher goals than they were put.

Thirdly, it is necessary to support the initiative of employees. To create an opportunity for workers of all levels to contribute their ideas to improve the life of the company and to highlight the implementation of the best of these ideas [13].

Finally, it should be especially noted the need to "vaccinate" the administrative culture of the right to a mistake and a non-valued attitude to subordinates. On a special place is the development of the "personnel reserve". Employees switch from the usual routine work to new tasks, increase interest, are inspired by the novelty and learn from each other. Thus, the company can also solve the task of developing employees and forming a "personnel reserve".

Traditional methods of doing business today do not guarantee success. They quickly become obsolete. The speed with which changes occur requires a way beyond the usual thinking, experience, past successes and the comfort zone of each employee and organization as a whole [14]. The future is for organizations that understand this.

Today it is no longer possible to treat employees like cogs in a car. The fate of the company is often in the hands of its employees, so it is beneficial for them to be happy. Therefore, they face the challenge of creating an environment in which people feel in their place, know why they work, feel their contribution to the common cause. Then they have eyes burning, there is energy, drive, there is an initiative and the desire to roll mountains. Yes, the times of gradual improvements and squeezing of employees in business have irretrievably gone. The hour has come for changing habits and paradigms, not template thinking and a qualitative breakthrough [15].

In order to develop superspeed on the trampoline of the past, the company needs changes first of all among managers. They are the main driving force of their organizations, because they develop strategies and inspire their implementation of employees. The present and future of the business depends on the pace of professional and personal development dynamics of managers. A lot depends on them. Underestimation of only a few minor features, in practice leads to the adoption of unsuccessful management decisions [16]. Today, it is not enough to teach the usual four functions of management and the application of the traditional approach to employee motivation - the carrot and the stick. First of all, it is necessary to change the paradigms of thinking of employees: to use both hemispheres of the brain, to develop creativity, to use methods of generating ideas, to transform the settings that keep us within the usual boundaries. More specifically, to consider what and how to train leaders today, you can, if you turn to the model of transformational leadership "pyramid of success." This theoretical program allows a different look at the existing picture of the business. How progressive the research program would not be, there will always be problems that can not be solved within its boundaries. And this will always serve as an impetus for the emergence of alternative approaches [17].

At the bottom of the pyramid are necessary, but insufficient skills for managing people and processes. However, now the leader needs to be a leader, the actual task is to empower others. The second level requires him to create a team and use its synergistic effect. It is very important to develop emotional intelligence (EQ) and be able to manage the team. Indeed, the opportunity to be flexible, be able to communicate with people, motivate them to realize their potential to the fullest - this is all the result of a high level of emotional intelligence of the leader, leader [18]. The "we-approach" is put forward. This means that the division is a thing of the past: "we are leaders, they are subordinates". In place of comes: we have created a result together, each 
made a contribution and is fully responsible for its result and the team as a whole. And this requires the head of the ability to recognize and believe in the potential of the subordinate, to inspire, to lead, to be an example, to give the right to make mistakes, and so on.

The apex of this pyramid of skills that turn a leader into a transformational leader is strategic thinking, coaching as an approach to management and change management. The development in these three directions gives managers the opportunity to connect to the outlet of opportunities and find access to the energy of change.

We can lead the process of managing change or they will control us, it depends only on us. The opinion of the "crowd" in the case of choosing the perception of the environment by the organization of the service sector now grows adequately to the growth of communicative interactions [19]. The ability of a leader to focus his subordinates on finding opportunities during a period of turbulent changes becomes the key to the organization's success. Therefore, it is necessary to learn how to team up ideas, develop a group solution, develop staff, transform beliefs, implement change.

In modern conditions, the leader can not do without innovation, in particular, gaming. The term gaming includes a variety of applications of games in the organization: from teaching methods and simulated offline games to online gaming, including game elements in the work activity of employees. Practically in every aspect of the organization's activity, one can find the use of gaming as a means of stimulating engagement, efficiency and responsibility. This is one of the best forms of learning and development, and an effective method for solving complex problems and dead-end problems, and a productive style of management activity.

Today, adaptability to change and the ability to inspire employees have become key qualities of modern leaders. The leader today is to treat the subordinate as a torch that needs to be ignited, and not to a vessel that needs to be filled. Then the employees will "burn their eyes" and they "fold the mountains". It is these organizations that will achieve outstanding results. At the same time, it is not so important what kind of decision the leader will eventually choose. It is important that the chosen solution really could move the company from a dead center and stimulate necessary changes [20].

\section{References / Сиисок литературы}

1. Borodai V.A. Torgovlja kak social'no-innovacionnyj process i faktor social'noj transformacii // Gumanitarnye i social'no-jekonomicheskie nauki, 2008. № 4. S. 181 - 184.

2. Borodai V.A. Social'no-institucional'nyj analiz societal'noj sfery torgovli v sovremennom obshhestve: diss.. d-r. soc. nauk. Novocherkassk, 2009. $415 \mathrm{~s}$.

3. Borodai V.A. Simulation assessment center in the service of the company as a factor in the accuracy and validity of the information about the employee // Professional Science, 2017. № 1. P. 22 - 32.

4. Borodai V.A. Crowd recruiting as the competence assessment of applicants service company // International Scientific Review, 2017. № 1 (32). P. 46 - 47.

5. Sivokoz N.V., Borodai V.A. Fasilitacija kak faktor jeffektivnoj sistemy upravlenija sovremennoj servisnoj kompanii // Jekonomika i socium, 2016. № 11-2 (30). S. 277 - 280.

6. Borodai V.A. Dudkina O.V. Problemnoe pole kouchinga v rossijskom biznese // Jekonomika i socium, 2014. № 1-3 (10). S. 422-425.

7. Borodai V.A. Brand of the employer as DNA of corporate culture of service company // European Research, 2017. № 1 (24). P. 34-35. DOI: 10.20861/2410-2873-2017-24-001.

8. Borodai V.A. Gerasimenko Ju.Ju. Korporativnaja kul'tura - zadannaja programma povyshenija jeffektivnosti biznesa // Jekonomika i socium, 2015. № 6-1 (19). S. 375 - 378.

9. Borodai V.A. Dudkina O.V. Algoritm planirovanija v turizme kak forma jekonomicheskogo vlijanija na rezul'taty dejatel'nosti // Podvodja itogi goda. Voprosy politologii, sociologii, filosofii, istorii, jekonomiki. Saratov: Akademija biznesa, 2016. S. 22 - 25.

10. Tkachuk M.S., Borodai V.A. Sohranenie korporativnyh cennostej kak ideologema kul'turnoj DNK kompanii // Jekonomika i socium, 2016. № 11-2 (30). S. 298 - 301.

11. Borodai V.A. Strategija i taktika sovremennyh predprijatij v uslovijah szhimajushhihsja rynkov // Biznes tehnologii v Rossii: teorija i praktika., materialy II mezhdunar. nauch.-prakt. konf. Saratov, 2015. Izdatel'skij dom «Akademija biznesa». S. 7 - 9.

12. Tret'jak A.A., Borodai V.A. Korporativnaja kul'tura kak osnovnoj marker pri formirovanii brenda kompanii // Jekonomika i socium, 2016. № 2 (21). S. 1298 - 1301.

13. Borodai V.A. HR-brending kak platforma pozicionirovanija kompanij-rabotodatelej // Jekonomika i socium, 2016. № 2 (21). S. 1209 - 1213.

14. Dudkina O.V. K voprosu o brendirovanii territorii goroda Rostova-na-Donu // Jekonomika i socium, 2016. № 2 (21). S. 296 - 299.

15. Borodai V.A.. Torgovlja v sovremennom obshhestve: social'no-institucional'nyj analiz: monogr. Rostov-naDonu: IPO PI JuFU, 2008. 332 s. 
16. Shostenko K.S., Borodai V.A. Strategicheskoe upravlenie - al'ternativy sovremennogo instrumentarija // Jekonomika i socium, 2016. № 2 (21). S. 1330 - 1333.

17. Dudkina O.V., Minasjan L.A., Saga A.S. Opyt ispol'zovanija infokommunikacionnyh tehnologij v provedenii marketingovogo issledovanija po voprosu o vizualizacii turistskogo potenciala goroda Rostova-na-Donu // Kul'tura i turizm kak instrumenty povyshenija chelovecheskogo potenciala nacii. Nacional'naja akademija turizma, Sankt-Peterburg, 2016.

18. Borodai V.A. Jemocional'naja kompetentnost' - kognitivnye osobennosti // Jekonomika sovremennogo obshhestva: aktual'nye voprosy antikrizisnogo upravlenija. Saratov: Akademija biznesa, 2015. S. 28 - 31.

19. Dudkina O.V. O vybore vosprijatija vneshnej sredy dlja predprijatij sfery servisa // Turizm i industrija gostepriimstva: sovremennoe sostojanie i tendencii razvitija. Materialy II mezhdunarodnoj nauchnoprakticheskoj konferencii, 2016. S. 175 - 177.

20. Borodai V.A. Anagenesis management innovation as ideologeme modern business-processes service company // International Scientific Review, 2017. № 2 (33). P. 30 - 32. 